\title{
Combined association analysis of interleukin 1-receptor antagonist (IL-1RN) variable number of tandem repeat (VNTR) and Haptoglobin 1/2 polymorphisms with type 2 diabetes mellitus risk
}

\author{
Habiba Al-Safar ${ }^{1,2}$, Wala Kamal ${ }^{3}$, Ahmed Hassoun ${ }^{4}$, Wael Almahmeed ${ }^{5}$ and Naushad Rais ${ }^{3^{*}}$
}

\begin{abstract}
Background: The polymorphism of Interleukin 1 receptor antagonist gene (IL-1RN), which encodes a natural antagonist of pro-inflammatory cytokines belonging to IL-1 family and Haptoglobin (HP) have been studied in various ethnic groups in association with Type 2 Diabetes Mellitus (T2DM) risk and related complications. However, there was no study available among the Emirati population. Hence, we designed a combined study on IL-1RN and HP polymorphism to evaluate their association with prevalence of T2DM, related complication and hypertension and also its interaction with obesity status among Emirati population.
\end{abstract}

Methods: IL-1RN and HP genotypes were determined in total 487 Emiratis divided in two groups of T2DM case $(n=271)$ and healthy controls $(n=215)$ by polymerase chain reaction (PCR) followed by gel electrophoresis. Gene-gene interaction and polymorphism-obesity interaction were determined by multivariate logistic regression analysis.

Results: We found that the frequencies of $I L-1 R N^{*} 1 I^{*} 1$ and HP2-2 genotypes were significantly higher in cases than control and were associated with increased T2DM risk with an odds ratio (OR) of 1.60 (95\% Cl 1.10-2.36) and 1.63 (95\% Cl 1.11-2.64), respectively. The association lack any interaction with obesity status. Associations with occurrences of T2DM related complications and hypertension were not observed.

Conclusions: We report an association of IL-1RN and HP polymorphism with T2DM risk independent of each other and of obesity status but no association with related complications and hypertension.

Keywords: Genetic polymorphism, Haptoglobin, Interleukin-1 receptor antagonist, Type 2 Diabetes Mellitus

\section{Background}

The recent update from 6th edition of the IDF Diabetes Atlas estimated 382 million people to have diabetes worldwide, with dramatic increases seen in countries all over the world including the Middle East North African region (MENA) region in which 34.6 million people, or $9.2 \%$ of the adult population have diabetes. This number is set to almost double to 67.9 million by 2035 , which is

\footnotetext{
*Correspondence: naushad@manipaldubai.com

${ }^{3}$ School of Life Sciences, Manipal University, P.O. Box-345050, Dubai, United Arab Emirates

Full list of author information is available at the end of the article
}

overwhelmingly due to increased prevalence of Type 2 Diabetes Mellitus (T2DM) in the region (IDF 6th Edition, 2013). More than $50 \%$ diabetic patients had major life threatening complications such as cardiovascular disease (CVD) like coronary heart disease, stroke, retinopathies and nephropathies associated with T2DM [1]. There is increasing evidence that genetic, environment and life style related factors contribute to the T2DM risk. However, genetic susceptibility appears to play a crucial role in the etiology and manifestation of the disease [2-4]. In recent years, numerous studies examining various ethnic groups have demonstrated an association of haptoglobin $(H P)$ 
genotypes, interleukin-1 receptor antagonist protein (IL-1Ra) levels with T2DM [5-7]. Indeed, IL-1Ra had been proposed as one of the potential therapeutic target and diagnostic biomarker of T2DM $[8,9]$.

$\mathrm{HP}$ is a plasma $\alpha 2$-glycoprotein which is synthesized by hepatocytes in response to infection or inflammation and binds free haemoglobin, thus preventing oxidative damage. The $H P$ gene is a polymorphic gene giving rise to 3 major genotypes HP1-1, HP2-1 and HP2-2. Protein encoded by HP1-1 genotype is a dimer, however the one encoded by HP2-1 and 2-2 exist as linear and circular polymers, respectively [10]. The frequency of the HP genotypes varies worldwide for example, the frequency of HP 1-1, HP1-2 and HP2-2 genotype in Western world were 16, 48 and $36 \%$, respectively [11-13]. HP genotypes have been linked to susceptibility to various T2DM related complications especially CVDs $[5,14]$ because of its involvement in states of oxidation and inflammation.

Interleukin-1 receptor antagonist gene $(I L-1 R N)$ encodes a naturally occurring competitive inhibitor of IL-1 that binds to the type I receptor and protects human pancreatic cells from IL-1 $\beta$-induced functional impairment and apoptosis [15, 16]. Recent work has demonstrated that Gastric inhibitory polypeptide (GIP) induced inflammatory and pro-lipolytic response which impairs insulin sensitivity of glucose uptake in human adipocytes is mediated by IL-1 $\alpha$ dependent signalling [17]. IL-1RN is abundantly expressed in adipose tissue in obese rodents and humans [18]. Serum levels of IL-1Ra are markedly increased in obesity $[19,20]$ and are considered as predictor of T2DM [20]. The $I L-1 R N$ gene demonstrates variable number of tandem repeat (VNTR) polymorphism within intron 2 due to an 86 bp sequence repeat. Six distinct alleles have been identified so far which correspond to 1, 2, 3, 4, 5 and 6 repeats of 86 bp sequence [21]. The alleles designated as $I L-1 R N * 1$ with 4 repeat and $I L-1 R N^{*} 2$ with 2 repeat are most frequently observed in the general populations and the other four alleles are rare. The repeated sequence at polymorphic site may have functional significance as it contains possible binding site for transcription factors [22]. There are not many reports available on the association of this polymorphism with T2DM risk and its interaction with hypertension and obesity status in Arab population. Taken together, we designed the present study on the combined analysis of polymorphisms of HP and $I L-1 R N$ genes in T2DM and related complications and its interaction with hypertension and obesity status in Emirati population, which largely remained unexplored with regards to genetic association studies on T2DM.

\section{Methods}

\section{Subjects and sample collection}

This study was conducted on four hundred and eighty seven $(n=486)$ unrelated Emiratis who were identified during their routine visit to a diabetes clinic in Dubai and Abu Dhabi, United Arab Emirates and agreed to take part in this study. The case group of 271 T2DM had mean age of $58 \pm 12$ years and consisted of $60 \%$ females. The control group consisted of 215 healthy individuals with mean age $45 \pm 16$ years and $68.37 \%$ female. All participants gave their informed consent in writing according to Helsinki's declaration (revision, 2008). There were several inclusion and exclusion criteria used in this study; Inclusion criteria: UAE National, diagnosed with T2DM and healthy individuals, able to give consent and above 18 years old. Exclusion Criteria: Non-UAE national, pregnant female, not be able to consent and less than 18 years old. The Ethics committees of the Dubai Health Authority and Sheikh Khalifa Medical City (SKMC) research ethics committee in the United Arab Emirates approved the study.

After taking an informed consent, each participant was asked to deliver $1 \mathrm{ml}$ of saliva into an Oragene kit OGR-500 (DNA Genotek, Ottwa, Canada) collection tube. The saliva samples were preserved for DNA extraction and genotyping later. The genomic DNA was extracted from saliva using prepITTM•L2P (DNA Genotek, Ottwa, Canada) DNA extraction kit in accordance with the manufacturer's instructions.

In addition, a clinical assessments and validated lifestyle questionnaire were completed at the clinic to study any correlation between lifestyle variables and genetic variation. An individual was classified as T2DM if the subject was (1) diagnosed with T2DM by a qualified physician, (2) on a prescribed drug treatment regimen for T2DM and (3) returned biochemical test results of a fasting plasma glucose level of at least $126 \mathrm{mg} / \mathrm{dl}$ based on the criteria outlined by the World Health Organization (WHO) consultation group report [23]. The individuals with BMI more than 30 were considered obese and those with a BMI less than 30 were grouped into the non-obese population. According to JNC 8 classification all the individuals with blood pressure more than 140/90 mmHg were considered hypertensive [24].

\section{PCR based genotyping for HP 1/2 polymorphism}

The HP genotypes were determined by polymerase chain reaction (PCR) followed by agarose gel electrophoresis. PCR primers, reaction and cycling conditions were performed as described previously by Koch et al. [25]. Briefly, $20 \mu \mathrm{L}$ reaction mixture contained $1 \mathrm{X}$ PCR buffer (as suggested by supplier), $2 \mathrm{U}$ of Taq polymerase (Qiagen, Hilden, Germany), 25-100 ng of DNA, $200 \mu \mathrm{M}$ each dNTPs and all four primers at final concentrations of $0.8 \mu \mathrm{M}$ each. After initial denaturation at $95{ }^{\circ} \mathrm{C}$ for $2 \mathrm{~min}$, the two-step thermocycling procedure consisted of denaturation at $95{ }^{\circ} \mathrm{C}$ for $1 \mathrm{~min}$, annealing and extension at $69{ }^{\circ} \mathrm{C}$ for $2 \mathrm{~min}$, repeated for 35 cycles, and followed by a final extension at $72{ }^{\circ} \mathrm{C}$ for $7 \mathrm{~min}$. All PCR reactions took place in the 
Thermo cyclers GeneAmp PCR systems 9700 (Applied Biosystems, Foster City, CA). For genotype determination the PCR products were separated on $1 \%$ agarose gels and visualized by ethidium bromide staining.

\section{IL-1RN gene intron 2 variable number tandem repeat polymorphism genotyping}

The $I L-1 R N$ gene intron 2 VNTR polymorphism was analyzed as previously described [26] under the following PCR conditions: denaturation at $94{ }^{\circ} \mathrm{C}$ for $5 \mathrm{~min}$, followed by 35 cycles at $94{ }^{\circ} \mathrm{C}$ for $30 \mathrm{~s}, 55^{\circ} \mathrm{C}$ for $30 \mathrm{~s}, 72{ }^{\circ} \mathrm{C}$ for $45 \mathrm{~s}$, and a final extension step at $72{ }^{\circ} \mathrm{C}$ for $7 \mathrm{~min}$ in Veriti 96 well Thermo Cycler (Applied Biosystems, Foster City, CA). The reaction was performed in $25 \mu \mathrm{L}$ reaction mixture containing 1X PCR buffer, 1.25 U of Taq polymerase (Qiagen, Hilden, Germany), 25-100 ng of DNA, $200 \mu \mathrm{M}$ each dNTP and primers at final concentrations of $1 \mu \mathrm{M}$ each.

\section{Statistical methods}

Statistical analyses were performed using STATA version 13 (STATA Corp., TX, USA). All continuous variables were expressed as the mean \pm SD or as percentages for categorical variables. The genotype frequencies were tested for the Hardy-Weinberg equilibrium using a $x^{2}$ test. Analysis of statistical power was done using the online Genetic Power Calculator. The Fisher exact test was used to compare the continuous variables between T2DM and healthy groups with respect to genotype distributions and allele frequencies. The Student's t test was used to compare the continuous variables between the T2DM and healthy groups. Fisher exact confidence intervals were drawn for relative risk estimates and calculated with a $95 \%$ confidence interval. The following gene transmission models were considered for haptogloin: (1) recessive effect (TT Vs CC $+\mathrm{CT}$ ), (2) a dominant effect (CC Vs CT + TT) and (3) additive effect of T allele. The association was evaluated by chi square test followed by logistic regression. A $p$ value of $<0.05$ was considered for statistical significance. The interaction of $H P$ genotypes $(1-1,1-2,2-2), I L-1 R N$ genotypes $(* 1 / * 1$ and $* 2 / * 2)$ with each other and with obesity and hypertension in relation to T2DM risk was also evaluated with logistic regression using the two by four tables.

\section{Results}

The demographic characteristics, clinical and biochemical parameters of T2DM patients and healthy control patients are described in Table 1 . The mean age and male/female ratios significantly differed in the affected individuals and healthy controls. The cases were significantly older than the controls ( $58 \pm 12$ Vs $45 \pm 16, p<$ 0.001 ), their mean BMI, lipid profile and blood pressure levels were also significantly different (Table 1 ). No significant differences were observed in these parameters
Table 1 Demographic, clinical and biochemical characteristics of T2DM patients and healthy subjects in the studied population

\begin{tabular}{lccc}
\hline & $\begin{array}{c}\text { T2DM patients } \\
n=271\end{array}$ & $\begin{array}{c}\text { Healthy subjects } \\
n=215\end{array}$ & $p$ \\
\hline Age (years) & $58 \pm 12$ & $45 \pm 16$ & $<0.0001$ \\
Male: Female Ratio & $110: 161$ & $69: 146$ & 0.05 \\
BMl & $31.99 \pm 6.3$ & $29.97 \pm 6.14$ & 0.0009 \\
Fasting Glucose (mmol/L) & $8.99 \pm 7.23$ & $5.63 \pm 7.23$ & $<0.0001$ \\
Systolic Blood Pressure & $129.97 \pm 17.24$ & $122.50 \pm 15.65$ & $<0.0001$ \\
(mmHg) & & & \\
Diastolic Blood Pressure & $70.0 \pm 11.0$ & $71.35 \pm 11.45$ & 0.6197 \\
(mmHg) & & & \\
HBA1c (mmol/L) & $7.6 \pm 1.6$ & $5.59 \pm 0.56$ & $<0.0001$ \\
Cholesterol (mmol/L) & $4.14 \pm 1.05$ & $4.49 \pm 0.96$ & 0.0001 \\
Triglycerides (mmol/L) & $1.46 \pm 0.83$ & $1.18 \pm 0.76$ & 0.0041 \\
HDL (mmol/L) & $1.22 \pm 0.49$ & $1.31 \pm 0.51$ & 0.1316 \\
LDL (mmol/L) & $2.30 \pm 0.91$ & $2.66 \pm 0.93$ & 0.0008 \\
\hline
\end{tabular}

$B M I$ body mass index, $H D L$ high-density lipoprotein, $L D L$ Low-density lipoprotein

between different $I L-1 R N$ genotypes, however HB1Ac level were higher in $H P 1-2+2-2$ genotypes than the HP1-1 homozygotes (Table 2). The genotype and allele frequency distribution for various alleles has been provided as Additional file 1 .

\section{Association of IL-1RN VNTR and HP $1 / 2$ polymorphism with T2DM risk regardless of obesity status}

The results of logistic regression analysis for three gene transmission models for HP 2 allele showed that odd ratios were significant only in dominant model $(H P 2-2+1-2 \mathrm{Vs}$ $1-1,[\mathrm{OR}=1.63(95 \% \mathrm{CI} 1.11-2.64, p=0.0442)]$ (Table 3) demonstrating HP 1-2 or 2-2 genotype as a risk factor for T2DM occurrence. Because of the absence of homozygote for other alleles, in case of IL-1RN VNTR polymorphism the association with T2DM risk was analyzed only $I L$ $1 R N^{*} 1 / * 1 \mathrm{Vs}$ all other observed genotypes in which $I L$ $1 R N^{*} 1 / * 1$ genotypes was found significantly associated with T2DM risk [OR 1.60 (95 \% CI 1.10-2.36), $p=$ $0.0192]$ as suggested by logistic regression analysis.

\section{Evaluation of interaction between two genetic polymorphisms and with obesity and hypertension in relation to T2DM risk}

Upon evaluation of interaction between $I L-1 R N$ and HP polymorphisms in T2DM, it was found that there was no significant interaction between HP 1-2 or 2-2 genotypes with $I L-1 R N{ }^{*} 1 /{ }^{*} 1$ genotype as analyzed by multivariate logistic regression analysis (Odd ratio of interaction variable 0.8064 [95 \% CI $0.2569-2.5320, p=0.7125]$ ) (Table 4) suggesting the association of these two polymorphisms with T2DM risk was independent of each other. These associations were also found independent of obesity status (Table 5). The allele and genotype frequency 
Table 2 Clinical and biochemical characteristics in different HP and IL-1RN genotypes

\begin{tabular}{|c|c|c|c|c|c|c|c|c|}
\hline & $\begin{array}{l}\mathrm{HB1AC} \\
(\mathrm{mmol} / \mathrm{L})\end{array}$ & $\begin{array}{l}\text { Cholesterol } \\
(\mathrm{mmol} / \mathrm{L})\end{array}$ & $\begin{array}{l}\text { Triglycerides } \\
\text { (mmol/L) }\end{array}$ & $\begin{array}{l}\mathrm{HDL} \\
(\mathrm{mmol} / \mathrm{L})\end{array}$ & $\begin{array}{l}\mathrm{LDL} \\
(\mathrm{mmol} / \mathrm{L})\end{array}$ & $\begin{array}{l}\mathrm{BMl} \\
\mathrm{Kg} / \mathrm{m}^{2}\end{array}$ & $\begin{array}{l}\mathrm{SBP} \\
\mathrm{mmHg}\end{array}$ & $\begin{array}{l}\text { DBP } \\
\mathrm{mmHg}\end{array}$ \\
\hline \multicolumn{9}{|l|}{ HP } \\
\hline $1-1$ & $6.54 \pm 1.06$ & $4.30 \pm 1.09$ & $1.27 \pm 0.893$ & $1.34 \pm 0.84$ & $2.54 \pm 1.02$ & $30.1 \pm 6.62$ & $123.6 \pm 17.6$ & $70.61 \pm 11.16$ \\
\hline $1-2+2-2$ & $7.15 \pm 1.74$ & $4.25 \pm 1.03$ & $1.39 \pm 0.801$ & $1.24 \pm 0.17$ & $2.41 \pm 0.92$ & $31.2 \pm 6.40$ & $127 \pm 16.7$ & $70.92 \pm 11.63$ \\
\hline$p^{\mathrm{a}}$ & 0.025 & 0.749 & 0.3417 & 0.067 & 0.368 & 0.173 & 0.12 & 0.836 \\
\hline \multicolumn{9}{|l|}{ IL-1RN } \\
\hline$*^{*} 1 /{ }^{*} 1$ & $7.36 \pm 4.86$ & $4.31 \pm 1.06$ & $1.36 \pm 0.82$ & $1.26 \pm 0.49$ & $2.48 \pm 0.97$ & $30.8 \pm 6.27$ & $126.5 \pm 16.9$ & $70.0 \pm 11.8$ \\
\hline$* 1 / * 2$ & $7.11 \pm 1.91$ & $4.15 \pm 0.99$ & $1.39 \pm 0.83$ & $1.24 \pm 0.56$ & $2.29 \pm 0.87$ & $31.6 \pm 6.54$ & $127.6 \pm 16.8$ & $72.5 \pm 10.6$ \\
\hline$p^{\mathrm{a}}$ & 0.663 & 0.216 & 0.773 & 0.751 & 0.106 & 0.232 & 0.548 & 0.045 \\
\hline
\end{tabular}

Data show mean \pm SD; ${ }^{a}$ student's t-test, SBP: Systolic Blood Pressure, DBP: Diastolic Blood Pressure

distribution of $I L-1 R N$ and $H P$ polymorphism in T2DM patients with or without hypertension and obesity also did not show any significant differences in genotype and allele frequencies between the subgroups (Table 6).

\section{$H P$ and IL-1RN polymorphism and complications in patients with T2DM}

The allele and genotype frequencies in T2DM patients with complications and without complications were not significantly different (Table 6) thus suggesting no association of these polymorphisms with the occurrence of T2DM related complications.

\section{Discussion}

T2DM is characterized by progressive $\beta$-cell failure and insulin resistance in which the inflammation and resulting immune response are thought to play a pathogenic role for disease development [27]. Pro-inflammatory cytokines like IL-1 $\beta$ induces apoptosis in insulin-producing $\beta$-cells [28] while CCL2 and TNF $\alpha$ are known to impair insulin signalling $[29,30]$, and therefore causing insulin resistance [31]. The present study focuses on two important genes $H P$ and $I L-1 R N$, the product of which are associated with inflammation and immune response, respectively. The active HP protein encoded by HP1-1 genotype induces the production of several cytokines and anti-inflammatory mediators when complexed with haemoglobin thus preventing oxidative damage through mechanisms including stabilization of the heme iron within haemoglobin [32, 33]. IL-Ra protein acts as an anti-inflammatory cytokine which is the natural inhibitor of pro-inflammatory cytokines such as IL-1 $\beta$. Larsen et al. [34] demonstrated that administration of exogenous IL-1Ra in T2DM patients could preserve endogenous insulin production and attenuate

Table 3 Analysis of association of T2DM with HP and IL-1RN genotypes in Emirati population

\begin{tabular}{|c|c|c|c|c|c|c|}
\hline \multirow{2}{*}{$\begin{array}{l}\text { HP Gene transmission } \\
\text { Recessive model }\end{array}$} & \multicolumn{2}{|l|}{ T2DM } & \multirow[t]{2}{*}{$p^{\mathrm{a}}$} & \multicolumn{3}{|c|}{ Logistic regression } \\
\hline & Yes (1) & No $(0)$ & & OR & $95 \% \mathrm{Cl}$ & $p$ \\
\hline $2-2$ & 132 & 92 & 0.2067 & 1.2606 & $0.8795-1.8066$ & 0.2073 \\
\hline $1-1+1-2$ & 140 & 123 & & & & \\
\hline \multicolumn{7}{|l|}{ Dominant model } \\
\hline $2-2+1-2$ & 235 & 171 & 0.0442 & 1.63 & $1.11-2.6399$ & 0.0447 \\
\hline $1-1$ & 37 & 44 & & & & \\
\hline \multicolumn{7}{|l|}{ Additive } \\
\hline $1-1(0)$ & 37 & 44 & 0.11648 & & & \\
\hline $1-2(1)$ & 103 & 79 & & & & \\
\hline $2-2(2)$ & 132 & 92 & & & & \\
\hline \multicolumn{7}{|l|}{ IL-1RN Genotypes } \\
\hline$* 1 / *_{1}$ & 200 & 138 & 0.019 & 1.60 & $1.10-2.36$ & 0.0192 \\
\hline${ }^{*} 1 /{ }^{*} 2+$ others & 69 & 76 & & & & \\
\hline
\end{tabular}


Table 4 Evaluation of gene-gene Interaction between HP and IL-1RN polymorphisms in T2DM

\begin{tabular}{|c|c|c|c|c|c|c|c|}
\hline \multirow{2}{*}{$\begin{array}{l}\text { HP } \\
\text { genotypes }\end{array}$} & \multirow{2}{*}{$\begin{array}{l}\text { IL-1RN } \\
\text { genotypes }\end{array}$} & \multicolumn{2}{|l|}{ T2DM } & \multirow[t]{2}{*}{$p^{a}$} & \multicolumn{3}{|c|}{ Logistic regression } \\
\hline & & Yes (1) & $\mathrm{NO}(0)$ & & $\mathrm{OR}$ & $95 \% \mathrm{Cl}$ & $p$ \\
\hline \multirow[t]{2}{*}{$1-2+2-2(1)$} & $*^{*} 1 / *^{*}$ & 170 & 111 & 0.0223 & 2.0800 & $0.7167-6.0364$ & 0.1779 \\
\hline & Others & 63 & 69 & & 1.6957 & $0.6362-4.5193$ & 0.2910 \\
\hline \multirow[t]{2}{*}{$1-1(0)$} & $*^{*} 1 /{ }^{*} 1$ & 28 & 25 & & 0.8064 & $0.2569-2.5320$ & 0.7125 \\
\hline & Others & 7 & 13 & & & & \\
\hline
\end{tabular}

${ }^{\text {a Overall model }}$

inflammation. Hence, the genetic polymorphism in these genes may be expected to be associated with T2DM in Emirati population. We designed the study to analyze (i) the association of $I L-1 R N$ VNTR and HP $1 / 2$ polymorphism with T2DM, related complication and hypertension individually; (ii) the association's potential interaction with each other and (iii) with obesity as it is one of the life style related factor associated with T2DM independently.

We observed a high frequency of $I l-1 R N^{* 1} 1 / * 1$ in our population which was only marginally associated with T2DM $(p=0.036)$ (See Additional file 1) and there was no association with either of the allele. Because of the absence of $* 2 / 2$ or other mutant homozygote the comparison was made only $I L-1 R N^{*} 1 /{ }^{*} 1 \mathrm{Vs} * 1 / * 2$ plus all other genotypes. Previously, Bid et al. [7] also demonstrated a high frequency of $I L-1 R N^{*} 1 / * 1$ genotypes in Indian T2DM patients. Moreover, allele $I L-I R N * 2$ has previously been demonstrated to be associated with enhanced in vitro production of IL-IRa by granulocytemacrophage colony-stimulating factor (GM-CSF)-stimulated monocytes [35]. In an in-vivo study [36], patients with type 1 diabetes carrying $I L-1 R N^{*} 1 / * 1$ genotype had $30 \%$ lower levels of plasma IL-1Ra compared with levels in patients carrying the $I L 1 R N^{*} 1 / * 2$ genotype further suggesting an enhancing effect of IL1RN*2 allele on IL-1Ra circulating levels in healthy carriers. We also observed a significantly higher risk of T2DM in individuals carrying IL-IRN *1/"1 genotype (OR 1.5963 (95 \% CI 1.0792-2.3612, $p=0.0192$ ) (Table 3 ). We identified marginally significant differences in the HP genotype and allele frequencies between the T2DM patients and healthy subjects. The frequencies of HP2-2 genotype and HP 2 allele were higher in T2DM group as compared to control (48.5\% Vs $33.8 \%)$ (see Additional file 1) and it carries significantly higher risk of T2DM but only in dominant model (Table 3). The HP genotype frequencies in this study were similar to those reported previously [11-13] in Caucasians. Several previous studies have investigated the effect of the $H P$ polymorphism on T2DM risk. A recent study by Adams et al. [5] reported that HP2-2 genotype was associated with T2DM risk in European American. A second report by Quaye et al. [37] found that the HP 2-2 phenotype was a risk factor for T2DM in a Ghana population. Upon literature exploration about the possible cause of this association we found that different $H P$ allele may lead to different circulating levels of HP protein $[38,39]$. High circulating HP protein as result of gene duplication (HP2) has been associated with metabolic syndrome, high blood pressure, and elevated glucose [40] and this could be possible explanation of the association of the HP polymorphism with T2DM risk. However, we did not find any correlation of $H P$ genotypes with diabetes dependent hypertension (Table 6).

In order to investigate gene-gene interaction, we analyzed the combined effect of $H P$ and $I L-1 R N$ polymorphism on, and their possible association with, T2DM. Multivariate logistic regression analysis results were obtained to evaluate the interaction which failed to show any interaction between two polymorphism (Table 4),

Table 5 Evaluation of interaction of obesity status with HP and IL-1RN polymorphisms and T2DM association in Emiratis

\begin{tabular}{|c|c|c|c|c|c|c|c|}
\hline \multirow[t]{2}{*}{ Obesity status } & \multirow[t]{2}{*}{ Genotypes } & \multicolumn{2}{|c|}{ T2DM } & \multirow[t]{2}{*}{$p^{a}$} & \multicolumn{3}{|c|}{ Logistic regression } \\
\hline & & Yes & No & & $\mathrm{OR}$ & $95 \% \mathrm{Cl}$ & $p$ \\
\hline \multirow[t]{2}{*}{$\mathrm{BMI}>30$} & $H P 1-2+2-2$ & 134 & 76 & 0.0675 & 1.4399 & $0.6986-2.96767$ & 0.3232 \\
\hline & HP1-1 & 19 & 12 & & 1.9792 & $0.7450-5.2575$ & 0.1708 \\
\hline \multirow[t]{2}{*}{$\mathrm{BMI}<30$} & $H P 1-2+2-2$ & 92 & 79 & & 0.7734 & $0.2678-2.233$ & 0.6348 \\
\hline & HP1-1 & 16 & 20 & & & & \\
\hline \multirow[t]{2}{*}{$\mathrm{BMI}>30$} & $\|-1 R N * 1 /{ }^{*} 1$ & 110 & 56 & 0.0989 & 0.7705 & $0.4435-1.3385$ & 0.3548 \\
\hline & $\| L-1 R N * 1 /{ }^{*} 2+$ others & 40 & 25 & & 1.1022 & $0.5598-2.1702$ & 0.7783 \\
\hline \multirow[t]{2}{*}{$\mathrm{BMI}<30$} & $\| L-1 R N * 1 / *^{*}$ & 85 & 76 & & 1.5934 & 0.7079-3.5866 & 0.2604 \\
\hline & $\operatorname{IL}-1 R N{ }^{*} 1 /{ }^{*} 2+$ others & 45 & 31 & & & & \\
\hline
\end{tabular}


Table 6 Allele and Genotype frequencies of IL-1RN VNTR and HP 1/2 polymorphisms in T2DM patients with or without complications, hypertension and obesity

\begin{tabular}{|c|c|c|c|c|c|c|c|c|c|}
\hline & \multirow{2}{*}{\multicolumn{2}{|c|}{$\frac{\text { Complications }}{N(\%)}$}} & \multirow[t]{3}{*}{$p^{a}$} & \multirow{2}{*}{\multicolumn{2}{|c|}{$\begin{array}{l}\text { Hypertension } \\
N(\%) \\
\end{array}$}} & \multirow[t]{3}{*}{$P^{a}$} & \multirow{2}{*}{\multicolumn{2}{|c|}{$\begin{array}{l}\text { Obesity } \\
N(\%) \\
\end{array}$}} & \multirow[t]{3}{*}{$p^{a}$} \\
\hline & & & & & & & & & \\
\hline & Yes & No & & Yes & No & & Yes & No & \\
\hline \multicolumn{10}{|l|}{$I L-I R N$} \\
\hline$*^{*} 1 /{ }^{*} 1$ & 77 (74.0 \%) & 79 (68.7 \%) & \multirow[t]{2}{*}{0.455} & $130(73.9 \%)$ & 65 (71.4\%) & \multirow[t]{2}{*}{0.666} & $110(73.3 \%)$ & 85 (65.4\%) & \multirow[t]{2}{*}{0.163} \\
\hline${ }^{*} 1 /{ }^{*} 2+$ others & 27 (26.0\%) & 36 (31.3\%) & & $46(26.1 \%)$ & $26(28.6 \%)$ & & $40(26.7 \%)$ & 45 (34.6 \%) & \\
\hline \multicolumn{10}{|l|}{ Allele Frequencies } \\
\hline$*_{1}$ & 0.87 & 0.83 & \multirow[t]{2}{*}{0.1573} & 0.87 & 0.86 & \multirow[t]{2}{*}{0.686} & 0.87 & 0.83 & \multirow[t]{2}{*}{0.1963} \\
\hline$*_{2}$ & 0.10 & 0.14 & & 0.10 & 0.11 & & 0.10 & 0.12 & \\
\hline \multicolumn{10}{|l|}{$H P$} \\
\hline $1-1$ & 15 (14.3\%) & $13(11.6 \%)$ & \multirow[t]{2}{*}{0.2885} & $28(15.9 \%)$ & $9(9.9 \%)$ & \multirow[t]{2}{*}{0.196} & 19 (12.4\%) & $16(14.8 \%)$ & \multirow[t]{2}{*}{0.5851} \\
\hline $1-2+2-2$ & 90 (85.7 \%) & $99(88.4 \%)$ & & $148(84.1 \%)$ & 82 (90.1 \%) & & 134 (87.6 \%) & $92(85.2 \%)$ & \\
\hline \multicolumn{10}{|l|}{ Allele frequencies } \\
\hline 1 & 0.33 & 0.30 & \multirow[t]{2}{*}{0.5353} & 0.34 & 0.30 & \multirow[t]{2}{*}{0.382} & 0.30 & 0.37 & \multirow[t]{2}{*}{0.1562} \\
\hline 2 & 0.67 & 0.70 & & 0.66 & 0.70 & & 0.70 & 0.63 & \\
\hline
\end{tabular}

${ }^{\mathrm{a}}$ Fisher exact test

suggesting these polymorphisms are associated with T2DM independent of each other. In addition, we also evaluated the effect of obesity status and possible interaction with these two gene polymorphism as obesity is one of the risk associated with T2DM. Moreover, in some studies the associations of SNPs in some of the T2DM candidate genes have previously been shown to be modulated by obesity status [41]. However, we did not observe any interaction of obesity status with $H P$ and $I L-1 R N$ polymorphism with regard to association with T2DM risk hence, it is unlikely to have cofounded the HP and $I L-1 R N$ associations describe here.

We also evaluated the effect of these polymorphisms on the incidences of T2DM related complications and hypertension which may be expected as variable circulating levels of HP and IL-1Ra in different genotypes as described elsewhere may affect the oxidative and inflammatory status in the body. To our surprise, we did not observe any association of $H P$ and $I L-1 R N$ genotypes and allele frequencies with T2DM related complications and hypertension (Table 6). One of the possible causes of no association may be due to small sample size in the subgroups created based on the absence and presence of any of the complications, resulting in low statistical power for analysis. Moreover, we took the different complications like CVD, stroke, nephropathies and retinopathies all together in the single group for the reason of not having enough samples in individual subgroups. Therefore, this study requires further confirmation with large sample size and all the complications needed to be analyzed individually. We also analyzed the association of different biochemical and clinical parameters of T2DM patients with $H P$ and $I L-1 R N$ genotypes; there was lack of association with any of these parameters except that the HBA1c levels were significantly higher in HP 1-2 and HP2-2 genotypes $(p=0.025)$ (Table 2$)$.

\section{Conclusion}

This is the first report on the association of $I L-1 R N$ and $H P$ with T2DM risk in Emirati population. This association is independent of obesity status. We did not find any association of these polymorphisms with T2DM related complications however; the levels of HBA1c were significantly higher in HP 1-2 and HP2-2 genotypes. There was no association of these genotypes with hypertension probably because of small sample size, hence require further confirmation.

\section{Ethics approval and consent to participate}

The Ethics committees of the Dubai Health Authority and Sheikh Khalifa Medical City (SKMC) research ethics committee in the United Arab Emirates approved the study. Written informed consent was obtained from all cases and controls.

\section{Availability of data and materials}

Summary data are available from the corresponding author as appropriate for meta-analyses. 


\section{Additional file}

Additional file 1: Table S1. Allele and Genotype frequencies of IL-IRN VNTR and HP1/2 polymorphisms in T2DM patients and healthy subjects regardless of obesity status. (DOCX $12 \mathrm{~kb}$ )

\section{Abbreviations \\ BMI: body mass index; DNA: deoxyribonucleic acid; GWAS: genome-wide association study; HLD: high density lipoprotein; IDF: International Diabetes Foundation; LDL: low density lipoprotein; SNP: single nucleotide polymorphisms; T2DM: Type 2 Diabetes Mellitus; TG: Triglyceride.}

\section{Competing interests}

All the authors declare no competing interest.

\section{Authors' contributions}

HAS, AH and NR conceived the study, HAS obtained the funding, HAS and NR designed the experiments, WK performed all laboratory work in Molecular Cell Biology laboratory at Khalifa University, HAS, AH and NR prepared the manuscript and performed all the data analyses with assistance from co-authors. AH and WA provided endless support in recruiting volunteers at Dubai Diabetes Clinic and Tawam Hospital. All authors read and approved the final manuscript.

\section{Acknowledgment}

We gratefully acknowledge the volunteers whose cooperation made this study possible. Grant from the Khalifa University through Khalifa Internal Research Fund (KIRF) is duly acknowledged.

\section{Funding}

This study was supported by a grant from the Khalifa University through Khalifa Internal Research Fund (KIRF).

\section{Author details}

${ }^{1}$ Khalifa University Center of Biotechnology, Khalifa University of Science, Technology \& Research, P.O. Box 127788, Abu Dhabi, United Arab Emirates. ${ }^{2}$ Khalifa University Center of Biotechnology, P.O. Box 127788, Abu Dhabi, United Arab Emirates. ${ }^{3}$ School of Life Sciences, Manipal University, P.O. Box-345050, Dubai, United Arab Emirates. ${ }^{4}$ Dubai Diabetes Centre, Dubai Health Authority, Dubai, United Arab Emirates. ${ }^{5}$ Institute of cardiac science, Sheikh Khalifa Medical City, Abu Dhabi, United Arab Emirates.

Received: 10 August 2015 Accepted: 19 March 2016

Published online: 29 March 2016

\section{References}

1. Bowden DW, Cox AJ, Freedman Bl, et al. Review of the diabetes heart study (DHS) family of studies: a comprehensively examined sample for genetic and epidemiological studies of type 2 diabetes and its complications. Rev Diabet Stud. 2010;7:188-201.

2. Flores-Martinez SE, Islas-Andrade S, Machorro-Lazo MV, et al. DNA polymorphism analysis of candidate genes for type 2 diabetes mellitus in a Mexican ethnic group. Ann Genet. 2004:47:339-48.

3. Radha V, Mohan V. Genetic predisposition to type 2 diabetes among Asian Indians. Indian J Med Res. 2007;125:259-74.

4. Elbein SC. The genetics of human noninsulin-dependent (type 2) diabetes mellitus. J Nutr. 1997:127:1891S-6S.

5. Adams JN, Cox AJ, Freedman BI, Langefeld CD, Carr JJ, Bowden DW. Genetic analysis of haptoglobin polymorphisms with cardiovascular disease and type 2 diabetes in the diabetes heart study. Cardiovasc Diabetol. 2013;12:31-40.

6. Shi X, Sun L, Wang L, et al. Haptoglobin 2-2 Genotype Is Associated with Increased Risk of Type 2 Diabetes Mellitus in Northern Chinese. Genet Testing Mol Biomark. 2012;16:563-8.

7. Bid HK, Konwar R, Agrawal CG, Banerjee M. Association of IL-4 and IL-1RN (receptor antagonist) gene variants and the risk of type 2 diabetes mellitus: A study in the north Indian population. Indian J Med Sci. 2008:62:259-66.

8. Böni-Schnetzler M, Donath MY. How biologics targeting the IL-1 system are being considered for the treatment of type 2 diabetes. Br J Clin Pharmacol. 2013;76:263-8.
9. Salomaa V, Havulinna A, Saarela O, et al. Thirty-One Novel Biomarkers as Predictors for Clinically Incident Diabetes. PLoS One. 2013;5:e10100.

10. Levy AP, Asleh R, Blum S, et al. Haptoglobin: basic and clinical aspects. Antioxid Redox Signal. 2010;12:293-304.

11. Langlois MR, Delanghe JR. Biological and clinical significance of haptoglobin polymorphism in humans. Clin Chem. 1996:42:1589-600.

12. Awadallah $\mathrm{S}$, Hamad M. The prevalence of type II diabetes mellitus is haptoglobin phenotype independent. Cytobios. 2000;101:145-50.

13. Bowman $\mathrm{BH}$, Kurosky A. Haptoglobin: the evolutionary product of duplication, unequal crossing over, and point mutation. Adv Hum Genet. 1982;12:189-261.

14. Levy AP. Haptoglobin genotype and vascular complications in patients with diabetes. N Engl J Med. 2000;343:969-70.

15. Dinarello CA. The role of the interleukin-1-receptor antagonist in blocking inflammation mediated by interleukin-1. N Engl J Med. 2000;343:732-4.

16. Maedler K, Sergeev P, Ris F, et al. Glucose-induced beta-cell production of IL-1 beta contributes to glucotoxicity in human pancreatic islets. J Clin Invest. 2002;110:851-60.

17. Timper K, Grisouard J, Sauter NS, et al. Glucose-dependent insulinotropic polypeptide induces cytokine expression, lipolysis, and insulin resistance in human adipocytes. Am J Physiol Endocrinol Metab. 2013;304:E1-E13.

18. Juge-Aubry CE, Somm E, Giusti V, et al. Adipose tissue is a major source of interleukin-1 receptor antagonist: upregulation in obesity and inflammation. Diabetes. 2003:52:1104-10

19. Juge-Aubry CE, Somm E, Chicheportiche R, et al. Regulatory effects of interleukin (IL)-1, interferon-beta, and IL-4 on the production of IL-1 receptor antagonist by human adipose tissue. J Clin Endocrinol Metab. 2004;89:2652-8.

20. Meier CA, Bobbioni E, Gabay C, Assimacopoulos-Jeannet F, Golay A, Dayer JM. IL-1 receptor antagonist serum levels are increased in human obesity: a possible link to the resistance to leptin? J Clin Endocrinol Metab. 2002;87:1184-8

21. Vamvakopoulos JE, Taylor CJ, Morris-Stiff GJ, Green C, Metcalfe S. The interleukin-1 receptor antagonist gene: a single-copy variant of the intron 2 variable number tandem repeat (VNTR) polymorphism. Eur J Immunogenet. 2002;29:337-40.

22. Tarlow JK, Blakemore Al, Lennard A, et al. Polymorphism in human IL-1 receptor antagonist gene intron 2 is caused by variable numbers of an 86-bp tandem repeat. Hum Genet. 1993:91:403-4.

23. Alberti KG, Zimmet PZ. Definition, diagnosis and classification of diabetes mellitus and its complications. Part 1: diagnosis and classification of diabetes mellitus provisional report of a WHO consultation. Diabet Med. 1998;15:539-53.

24. James PA, Oparil S, Carter BL, Cushman WC, et al. Evidence-Based Guidelines for the Management of High Blood Pressure in Adults: Report From the Panel Members Appointed to the Eighth Joint National Committee (JNC 8). JAMA. 2014;311:507-20.

25. Koch W, Latz W, Eichinger M, et al. Genotyping of the common haptoglobin Hp 1/2 polymorphism based on PCR. Clin Chem. 2002:48:1377-82.

26. Grover S, Tandon S, Misra R, Aggarwal A. Interleukin-1 receptor antagonist gene polymorphism in patients with rheumatoid arthritis in India. Indian J Med Res. 2006;123:815-20.

27. Kolb H, Mandrup-Poulsen T. An immune origin of type 2 diabetes. Diabetologia. 2005:48:1038-50

28. Dinarello CA. Biologic basis for interleukin-1 in disease. Blood. 1996:87:2095-47.

29. Kawazoe $Y$, Naka T, Fujimoto M, et al. Signal transducer and activator of transcription (STAT)-induced STAT inhibitor 1 (SSI-1)/suppressor of cytokine signaling 1 (SOCS1) inhibits insulin signal transduction pathway through modulating insulin receptor substrate 1 (IRS-1) phosphorylation. J Exp Med. 2001;193:263-9.

30. Shi H, Tzameli I, Bjorbaek C, Flier JS. Suppressor of cytokine signaling 3 is a physiological regulator of adipocyte insulin signaling. J Biol Chem. 2004:279:34733-40.

31. Herder C, Haastert B, Muller-Scholze S, et al. Association of systemic chemokine concentrations with impaired glucose tolerance and type 2 diabetes: results from the Cooperative Health Research in the Region of Augsburg Survey S4 (KORA S4). Diabetes. 2005;54 Suppl 2:S11-7.

32. Schaer CA, Schoedon G, Imhof A, Kurrer MO, Schaer DJ. Constitutive endocytosis of CD163 mediates hemoglobin-heme uptake and determines the noninflammatory and protective transcriptional response of macrophages to hemoglobin. Circ Res. 2006;99:943-50.

33. Melamed-Frank M, Lache $\mathrm{O}$, Enav Bl, et al. Structure-function analysis of the antioxidant properties of haptoglobin. Blood. 2001;98:3693-8. 
34. Larsen CM, Faulenbach $M$, Vaag A, et al. Interleukin-1-receptor antagonist in type 2 diabetes mellitus. N Engl J Med. 2007;356:1517-26.

35. Danis VA, Millington M, Hyland VJ, et al. Cytokine production by normal human monocytes: inter-subject variation and relationship to an IL-1 receptor antagonist (IL-IRa) gene polymorphism. Clin Exp Immunol. 1995;99:303-10.

36. Mandrup-Poulsen T, Pociot F, Molvig J, et al. Monokine antagonism is reduced in patients with IDDM. Diabetes. 1994;43:1242-7.

37. Quaye IK, Ababio G, Amoah AG. Haptoglobin 2-2 phenotype is a risk factor for type 2 diabetes in Ghana. J Atheroscler Thromb. 2006;13:90-4.

38. De Bacquer D, De Backer G, Langlois M, Delanghe J, Kesteloot H, Kornitzer M. Haptoglobin polymorphism as a risk factor for coronary heart disease mortality. Atherosclerosis. 2001;157:161-6.

39. Froguel P, Ndiaye NC, Bonnefond A, et al. A genome-wide association study identifies rs2000999 as a strong genetic determinant of circulating haptoglobin levels. PLoS One. 2012;7:e32327.

40. Hamalainen P, Saltevo J, Kautiainen H, Mantyselka P, Vanhala M. Erythropoietin, ferritin, haptoglobin, hemoglobin and transferring receptor in metabolic syndrome: a case control study. Cardiovasc Diabetol. 2012;11:116-20.

41. Cauchi $\mathrm{S}$, Nead KT, Choquet $\mathrm{H}$, et al. The genetic susceptibility to type 2 diabetes may be modulated by obesity status: implications for association studies. BMC Med Genet. 2008;9:45-50.

\section{Submit your next manuscript to BioMed Central and we will help you at every step:}

- We accept pre-submission inquiries

- Our selector tool helps you to find the most relevant journal

- We provide round the clock customer support

- Convenient online submission

- Thorough peer review

- Inclusion in PubMed and all major indexing services

- Maximum visibility for your research

Submit your manuscript at www.biomedcentral.com/submit

) Biomed Central 